Philipp Büsch

\title{
Der Wettbewerbsgedanke im Energierecht
}

Die Diskussion um die Reform des Energiewirtschaftsgesetzes zwischen 1948 und 1973

[The Concept of Competition in Energy Law. The Discussion on the Reform of the Energy Industry Act between 1948 and 1973.]

Published in German.

Philipp Büsch traces the historical course of the debate about a reform of the German energy law in the postwar period and explores how the interests of the different pressure groups influenced the legislative process. He points out the difficulties

PHILIPP BÜSCH

Der Wettbewerbsgedanke im Energierecht

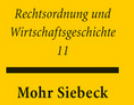

2014. XIV, 227 pages. ROWG 11

ISBN 978-3-16-153402-7

cloth $89,00 €$

ISBN 978-3-16-160616-8

eBook PDF 89,00€
Order now:

https://www.mohrsiebeck.com/en/book/der-wettbewerbsgedanke-im-energierecht-9783161534027?no_cache=1 order@mohrsiebeck.com

Phone: $+49(0) 7071-923-17$

Fax: $+49(0) 7071-51104$ 